\title{
Analisis Differensiasi Produk dan Citra Merek terhadap Keputusan Pembelian Konsumen pada Sepeda Motor Merek Yamaha Mio di Kota Langsa
}

\author{
Analysis of Product Differentation and Brand Image toward Consumer \\ Purchasing Decisions on Yamaha Mio Brand of Motorcycle in Langsa City
}

\author{
Maulana Rahman ${ }^{1)}$, Nawa Suhayani ${ }^{2)}$ \\ ${ }^{1,2)}$ Fakultas Ekonomi, Universitas Samudra, Kota Langsa \\ e-mail korespondensi: maulanarahman@unsam.ac.id
}

\begin{tabular}{|l|}
\hline Info Artikel \\
\hline Riwayat Artikel : \\
Diterima: 26 Maret 2020 \\
Disetujui: 21 Juni 2020 \\
Dipublikasikan: Juli 2020 \\
\hline Nomor DOI \\
10.33059/jseb.v11i2.2195 \\
Cara Mensitasi : \\
Rahman, M. \& Suhayani, N. \\
2020. Analisis Differensiasi \\
Produk dan Citra Merek \\
terhadap Keputusan Pembelian \\
Konsumen pada Sepeda Motor \\
Merek Yamaha Mio di Kota \\
Langsa. Jurnal Samudra \\
Ekonomi dan Bisnis. 11(2): \\
227-236.
\end{tabular}

Abstrak

Penelitian ini bertujuan untuk menganalisis diferensiasi produk dan citra merek terhadap keputusan pembelian konsumen, dengan studi kasus pada merek Yamaha Mio di Kota Langsa. Metode regresi berganda digunakan untuk menganalisis data. Hasil penelitian menunjukkan bahwa secara parsial, differensiasi produk maupun citra merek memiliki pengaruh positif dan signifikan terhadap keputusan pembelian konsumen. Secara simultan, kedua variabel independen terbukti memiliki pengaruh yang signifikan terhadap variabel dependen. Dengan demikian, apabila perusahaan menerapkan strategistrategi terkait differensiasi produk serta citra merek, baik secara parsial maupun simultan, maka akan memperkuat keputusan pembelian yang dilakukan konsumen atas produk yang ditawarkan. Namun demikian, analisis determinasi mengidentifikasi masih adanya beberapa faktor utama yang dinilai mempengaruhi keputusan pembelian konsumen namun tidak dicakup dalam model penelitian ini.

Kata Kunci: Differensiasi Produk, Citra Merek, Keputusan Pembelian Konsumen.

\begin{tabular}{|c|c|}
\hline Article Info & Abstract \\
\hline $\begin{array}{l}\text { Article History: } \\
\text { Received: } 26 \text { March } 2020 \\
\text { Accepted: } 21 \text { June } 2020 \\
\text { Published: July } 2020\end{array}$ & $\begin{array}{l}\text { This study aims to analyze product differentiation and brand image on the } \\
\text { customer purchase decision, with a case study of the Yamaha Mio brand of } \\
\text { matic-bike in Langsa City. Multiple regression method was used to analyze } \\
\text { data.. The results showed that partially, product differentiation and brand }\end{array}$ \\
\hline $\begin{array}{l}\text { DOI Number: } \\
\text { 10.33059/jseb.v11i2.2195 } \\
\text { How to cite : } \\
\text { Rahman, M. \& Suhayani, N. } \\
\text { 2020. Analisis Differensiasi } \\
\text { Produk dan Citra Merek } \\
\text { terhadap Keputusan } \\
\text { Pembelian Konsumen pada } \\
\text { Sepeda Motor Merek Yamaha }\end{array}$ & $\begin{array}{l}\text { image had a positive and significant influence on consumer purchasing } \\
\text { decisions. Simultaneously, the two independent variables were also obtained to } \\
\text { have a significant influence on dependent variable. Thus, if the company } \\
\text { implements strategies related to product differentiation and brand image, } \\
\text { partially or simultaneously, it will strengthen the purchasing decisions made by } \\
\text { consumers for products offered. However, the determination analysis identifies } \\
\text { that there are several main factors that are considered to influence consumer } \\
\text { purchasing decisions but are not included in this research model. }\end{array}$ \\
\hline $\begin{array}{l}\text { Mio di Kota Langsa. Jurnal } \\
\text { Samudra Ekonomi dan } \\
\text { Bisnis. 11(2): 227-236. }\end{array}$ & $\begin{array}{l}\text { Keywords: Product Differentiation, Brand Image, Consumer Purchase } \\
\text { Decisions. }\end{array}$ \\
\hline
\end{tabular}




\section{PENDAHULUAN}

Adanya persaingan yang ketat di antara pasar sepeda motor Indonesia membuat perusahaan sepeda motor di Indonesia untuk terus berusaha meningkatkan kualitas produknya. Upaya ditujukan untuk dapat memenuhi kebutuhan dan keinginan masyarakat yang masih relatif menginginkan alat transportasi yang mempunyai bentuk, keistimewaan, mutu kinerja dan gaya yang terkesan modern, efisien dan efektif (Ristiawan \& Farida, 2015; Angio, 2013; Setiadi, 2011). Sebelumnya pasar sepeda motor matic di Indonesia tidak berkembang karena adanya persepsi bahwa sepeda motor matic berharga mahal karena teknologinya memang mahal. Untuk mematahkan pesepsi itu, berdasarkan hasil wawancara awal dengan pemilik showroom sepeda motor produksi Yamaha di Kota Langsa, Yamaha sebagai produsen berani menanam investasi yang cukup besar untuk menyamakan harga sepeda motor matic produksi mereka yang diberi merek Mio dengan motor manual.

Perubahan yang mendasar berkenaan dengan cara pemikiran pemasaran adalah paradigma dari penjualan menjadi penciptaan pelanggan. Sekarang ini kondisi kekuatan pasar ada di tangan pembeli, sehingga perusahaan harus mampu mengetahui dan menciptakan suatu produk yang sesuai dengan keinginan, kebutuhan, persepsi dan gaya hidup guna mencapai kepuasan pelanggan (Gunawan 2012; Alma, 2014). Dengan demikian, perusahaan harus mampu menciptakan keunggulan atas produknya dalam persepsi pelanggan sehingga pandangan baik pelanggan atas produk terus ada dalam benaknya.

Dengan adanya persepsi yang positif atau suatu produk, maka pelanggan akan memiliki keyakinan dalam membuat keputusan pembeliannya atas produk yang bersangkutan. Keputusan pembelian adalah sebuah proses dimana konsumen mengenal masalahnya, mencari informasi mengenai produk atau merek tertentu dan mengevaluasi seberapa baik masing-masing alternatif itu dapat memecahkan masalahnya, yang kemudian mengarah kepada keputusan pembelian (Kertajaya, 2011; Kotler \& Armstrong, 2012). Dengan demikian bahwa keputusan pembelian yang dilakukan oleh konsumen untuk menentukan pemilihan satu tindakan atas dua atau lebih pilihan alternatif.

Dalam persaingan memasarkan produknya, perusahaan perlu membangun strategi pemasaran yang baik untuk mendorong ataupun memperkuat keputusan pembelian dari konsumen atas produk-produk mereka (Kotler \& Keller, 2012; Ferrinadewi, 2010; Ratri, 2010). Strategi yang harus dilakukan dalam upaya mencapai target pemasaran dimulai dari dalam perusahaan, khususnya produk yang diciptakan oleh perusahaan.

Dua faktor utama yang dinilai mempengaruhi keputusan pembelian konsumen terhadap sepeda motor merek Yamaha Mio adalah differensiasi produk serta citra merek (Gunawan, 2012; Kertajaya, 2011; Kotler \& Keller, 2012; Tjiptono, 2011; Ratri, 2010). Berdasarkan landasan pemikiran ini, maka penelitian ini ditujukan untuk menganalisis pengaruh dari differensiasi produk dan citra merek sebagai strategi untuk mempengaruhi keputusan pembelian konsumen untuk produk sepeda motor matic merek Yamaha Mio. Lokasi penelitian di Kota Langsa.

\section{Differensiasi Produk}

Differensiasi produk adalah semua upaya yang dilakukan untuk membedakan diri dari pesaing lain baik konten (what to offer), konteks (how to offer), dan infrastruktur (enabler) sehingga tidak mudah ditiru oleh pesaing (Kertajaya, 2011; Porter, 2018). Differensiasi konten adalah dimensi differensiasi yang menunjuk pada "value" apa yang 
ditawarkan konsumen. Differensiasi produk juga merupakan kegiatan memodifikasi produk agar lebih menarik yang berkaitan dengan mengubah sejumlah karakteristik produk, seperti kemasan dan tema promosi tanpa mengubah spesifikasi produk, meskipun itu diperbolehkan (Alma, 2014; Schiffman \& Kanuk, 2008; Tjiptono, 2008).

Sebagian besar pengguna sepeda motor di Kota Langsa menggunakan sepeda motor matic, salah satunya mereknya adalah Yamaha Mio. Dari wawancara awal terhadap beberapa pengguna sepeda motor Yamaha Mio berhubungan dengan diferensiasi produk, mereka menyatakan bahwa belum ada sesuatu yang unik dari motor Matic Yamaha Mio baik dari segi desain produk maupun aspek lainnya. Desain motor Yamaha Mio cenderung monoton, dimana desain produknya tidak jauh berbeda dari Yamaha Mio produksi tahun-tahun sebelumnya.

Lebih lanjut, para pengguna yang diwawancarai tersebut menyatakan bahwa saat ini terlihat begitu banyak merek sepeda motor dengan berbagai bentuk, keistimewaan, mutu kinerja, dan gaya yang berbeda satu sama lain, Pasar sepeda motor di Indonesia juga dinilaai telah berkembang dengan pesat selama beberapa tahun terakhir. Dengan demikian, inovasi-inovasi yang ditawarkan harus dapat merupakan perbedaan antara produknya dengan produk pesaing.

Differensiasi produk karenanya diharapkan sebagai suatu strategi yang dapat mendatangkan nilai ke konsumen (Yanti et al., 2013; Gunawan, 2012; Porter, 2018). Differensiasi perusahaan haruslah merupakan keunggulan dibandingkan pesaing dan mencerminkan keunggulan dari produk yang dikeluarkan. Selain itu, differensiasi yang dimunculkan diharapkan bersifat kokoh dan sustainable, sehingga perusahaan memiliki keunikan yang tidak bisa ditiru pesaing (Yanti et al, 2013; Tjiptono, 2008; Setiadi, 2011).
Produk-produk yang mempunyai tipe differensiasi bersifat unik dan tidak mudah ditiru oleh para pesaingnya dinilai bisa memperkuat keputusan konsumen untuk membeli produk tersebut. Berdasarkan hasil telaah ini, maka hipotesis pertama yang dimunculkan dalam penelitian ini adalah:

H1 : Differensiasi produk secara parsial berpengaruh secara signifikan terhadap keputusan pembelian konsumen pada sepeda motor merek Yamaha Mio di Kota Langsa.

\section{Citra Merek}

Selain differensiasi produk, citra merek juga dinilai menentukan konsumen dalam melakukan pembelian sepeda motor. Yang dimaksud dengan citra merek (brand image) adalah deskripsi mengenai asosiasi dan keyakinan konsumen terhadap merek tertentu (Tjiptono, 2011; Prasetijo \& Ihalauw, 2005). Citra merek merupakan proses dimana seseorang memilih, mengorganisasikan, dan mengartikan masukan informasi untuk menciptakan suatu gambaran yang berarti (Kotler \& Armstrong, 2012; Ratri, 2010; Kotler \& Keller, 2012).

Berdasarkan hasil wawancara awal diidentifikasi bahwa sebagian konsumen berpendapat bahwa motor Yamaha Mio cenderung boros bahan bakar. Hal ini dinilai berpengaruh terhadap citra merek Yamaha Mio, dimana citra merek Yamaha Mio di benak konsumen adalah sepeda motor matic yang tidak irit bahan bakar. Ditambah lagi adanya persaingan motor matic merek lainnya yang memunculkan konsep hemat bahan bakar, yang selanjutnya membuat citra merek Yamaha Mio menurun di mata konsumen.

Citra merek adalah deskripsi tentang asosiasi dan keyakinan konsumen terhadap merek tertentu (Tjiptono, 2008; Gunawan, 2012; Ferrinadewi, 2010). Hal ini karena jika konsumen sudah percaya pada suatu merek 
tertentu maka konsumen tentu memilih melakukan pembelian pada merek dipercayai tersebut. Dengan kata lain, citra merek merupakan faktor yang mempengaruhi pembelian. Citra merek adalah persepsi atau emosional beralasan bahwa konsumen melekat pada produk tertentu (Gunawan, 2012; Angio, 2013; Kertajaya, 2011).

Produk dengan citra merek yang baik memberikan rasa nyaman serta pandangan masyarakat yang positif pada merek produk tersebut sehingga penjualan produk itu akan mengalami peningkatan. Semakin baik citra suatu merek maka semakin tinggi keputusan konsumen untuk melakukan pembelian (Ristiawan \& Farida, 2015; Mahmudah \& Tiarawati, 2014; Kotler \& Armstrong, 2012). Dengan demikian, hipotesis kedua yang dimunculkan dalam penelitian ini adalah:

H2 : Citra merek secara parsial berpengaruh secara signifikan terhadap keputusan pembelian konsumen terhadap sepeda motor merek Yamaha Mio di Kota Langsa.

Penelitian ini selanjutnya menganalisis pengaruh simultan dari kedua variabel independen, yaitu differensiasi produk dan citra merek, terhadap keputusan pembelian konsumen terhadap sepeda motor merek Yamaha Mio. Hipotesis ketiga yang dimunculkan dalam penelitian ini adalah:

H3 : Secara simultan, differensiasi produk dan citra merek berpengaruh secara signifikan terhadap keputusan pembelian konsumen terhadap sepeda motor merek Yamaha Mio di Kota Langsa.

\section{METODE PENELITIAN}

Obyek penelitian ini adalah sepeda motor merek Yamaha Mio, dengan lokasi di Kota Langsa. Data primer utaama dikumpulkan melalui instrumen kuesioner, kemudian didukung oleh hasil observasi. Kuesioner yang digunakan dalam penelitian ini merujuk pada format yang digunakan oleh Yanti et al. (2013) serta Ristiawan \& Farida (2015).

Sebelum digunakan untuk mengumpulkan data riil, kuesioner terlebih dahulu di uji derajat validitas dan reliabilitasnya (Sunyoto, 2014; Prasetyo \& Jannah, 2016). Pengujian dilakukan pada 30 orang yang tidak termasuk sebagai responden penelitian ini. Hasil pengujian validitas ditunjukkan di dalam Tabel 1, sementara hasil uji reliabilitas dirangkum dalam Tabel 2.

Hasil uji validitas dalam Tabel 1 mengidentifikasikan bahwa semua item pernyataan yang diajukan dalam kuesioner penelitian ini mengenai differensiasi produk, citra merek dan keputusan pembelian konsumen sebanyak 15 buah memiliki nilai $r$-hitung $>0,3$. Berdasarkan kriteria penilaian yang ditetapkan (Sunyoto, 2014; Ghozali, 2011), hasil pengujian menyatakan seluruh item pernyataan yang diajukan terbukti valid. Dengan demikian, berdasarkan hasil uji validitas dinyatakan bahwa kuesioner ini bisa digunakan sebagai instrumen pengumpulan data penelitian.

Hasil uji reliabilitas yang dirangkum dalam Tabel 2 menunjukkan nilai Cronbach Alpha untuk masing-masing variabel yang dianalisis adalah lebih besar dari 0,6. Sehingga kriteria pengujian yang ditetapkan (Ghozali, 2011; Sugiyono, 2012), maka dinyatakan seluruh item pernyataan yang diajukan dalam kuesioner ini terbukti reliabel. Dengan demikian, berdasarkan hasil uji reliabilitas dinyatakan kuesioner ini bisa digunakan sebagai instrumen pengumpulan data penelitian.

Populasi adalah seluruh pengguna sepeda motor matic merek Yamaha Mio di Kota Langsa. Karena tidak terdapat data jumlah pengguna tersebut secara pasti, maka penentuan sampel ditentukan menggunakan teknik unknown population (Prasetyo \& 
Jannah, 2016). Berdasarkan teknik itu diperoleh jumlah 96 orang pengguna sebagai sampel. Pemilihan sampel menggunakan metode accidental sampling, yaitu siapa saja anggota populasi yang secara kebetulan dijumpai saat pelaksanaan penelitian dan dinilai sesuai sebagai sampel maka anggota populasi tersebut dijadikan sebagai responden dalam penelitian ini (Sugiyono, 2012; Prasetyo \& Jannah, 2016).

\section{Metode Analisis Data}

Metode analisis data yang digunakan dalam penelitian ini yaitu regresi linier berganda. Model penelitian meliputi tiga variabel yang dianalisis. Variabel independen meliputi differensiasi produk (X1) dan citra merek (X2); sementara variabel dependen adalah keputusan pembelian (Y). Analisis regresi berganda ditujukan untuk mengidentifikasi besaran pengaruh dari masingmasing variabel independen terhadap variabel dependen (Sugiyono, 2012; Prasetyo \& Jannah, 2016).).

Tahap analisis data dilanjutkan dengan pengujian atas tiga hipotesis penelitian. Hipotesis 1 dan 2 di uji menggunakan uji parsial atau uji t (t-test); sedangkan Hipotesis 3 di uji menggunakan uji simultan atau uji $\mathrm{F}$ (F-test) (Ghozali, 2011; Sunyoto, 2014). Analisis data juga diperkuat oleh analisis determinasi yang menyatakan besaran kontribusi kedua variabel independen dalam menjelaskan perubahan variabel dependen.

Tabel 1. Hasil Uji Validitas

\begin{tabular}{ccccc}
\hline Variabel & Indikator & r-hitung & Kriteria r-tabel & Kesimpulan \\
\hline & X1.1 & 0,597 & & Valid \\
Differensiasi Produk & X1.2 & 0,732 & & Valid \\
(X1) & X1.3 & 0,672 & $>0,3$ & Valid \\
& X1.4 & 0,737 & & Valid \\
& X1.5 & 0,686 & & Valid \\
\hline & X2.1 & 0,689 & & Valid \\
Citra Merek & X2.2 & 0,696 & & Valid \\
(X2) & X2.3 & 0,746 & $>0,3$ & Valid \\
& X2.4 & 0,775 & & Valid \\
Xeputusan Pembelian & Y.1 & 0,675 & & Valid \\
(Y) & Y.2 & 0,854 & & Valid \\
& Y.3 & 0,588 & & Valid \\
& Y.4 & 0,721 & $>0,3$ & Valid \\
& Y.5 & 0,638 & & Valid \\
\hline
\end{tabular}

Sumber: Data primer diolah, 2019.

Tabel 2. Hasil Uji Reliabilitas

\begin{tabular}{lccc}
\hline \multicolumn{1}{c}{ Variabel } & Cronbach's Alpha & Kriteria Koefisien & Kesimpulan \\
\hline Differensiasi Produk (X1) & 0,712 & & Reliabel \\
Citra Merek (X2) & 0,762 & $>0,6$ & Reliabel \\
Keputusan Pembelian (Y) & 0,782 & & Reliabel \\
\hline
\end{tabular}

Sumber: Data primer diolah, 2019. 
Tabel 3. Karakteristik Responden

\begin{tabular}{|c|c|c|c|}
\hline No. & Karakteristik & Frekuensi (orang) & Frekuensi (persen) \\
\hline \multicolumn{4}{|c|}{ Jenis Kelamin : } \\
\hline 1 & Laki-Laki & 41 & 42,70 \\
\hline 2 & Perempuan & 55 & 57,30 \\
\hline \multicolumn{4}{|c|}{ Usia : } \\
\hline 1 & $<20$ tahun & 11 & 11,45 \\
\hline 2 & $20-40$ tahun & 44 & 45,83 \\
\hline 3 & $>40$ tahun & 41 & 42,72 \\
\hline \multicolumn{4}{|c|}{ Pekerjaan : } \\
\hline 1 & Pegawai Negeri & 29 & 30,20 \\
\hline 2 & Karyawan BUMN/Swasta & 32 & 33,33 \\
\hline 3 & Mahasiswa & 19 & 19,79 \\
\hline 4 & Wiraswasta & 11 & 11,45 \\
\hline 5 & Lainnya & 5 & 5,23 \\
\hline \multicolumn{4}{|c|}{ Pendapatan : } \\
\hline 1 & Rp. 1 juta - Rp. 3 juta & 42 & 43,75 \\
\hline 2 & Rp. 3 juta - Rp. 4 juta & 28 & 29,16 \\
\hline \multirow[t]{2}{*}{3} & $>$ Rp. 4 juta & 26 & 27,09 \\
\hline & Total & 96 & 100,00 \\
\hline
\end{tabular}

Sumber: Data primer diolah, 2019.

\section{HASIL ANALISIS}

\section{Karakteristik Responden}

Bagian ini menjelaskan tentang karakteristik dari 96 responden penelitian ini. Secara umum, karakteristik konsumen bisa mempengaruhi keputusan pembelian yang diambilnya. Penjelasan tentang karakteristik responden meliputi jenis kelamin, usia, pekerjaan, dan pendapatan, yang terangkum dalam Tabel 3.

Berdasarkan Tabel 3 dapat diidentifikasi bahwa mayoritas responden penelitian ini mempunyai karakteristik jenis kelamin perempuan (55 orang atau 57,30 persen); berada pada rentang usia 20 sampai 40 tahun (44 orang atau 45,83 persen); memiliki pekerjaan sebagai karyawan BUMN/Swasta (32 orang atau 33,33 persen); serta, memiliki tingkat pendapatan sebesar Rp. 1 juta sampai Rp. 3 juta (42 tahun atau 43,75 persen).

\section{Hasil Analisis Regresi Berganda}

Berdasarkan hasil analisis data yang dirangkum dalam Tabel 4 dapat dibuat persamaan regresi linier berganda dari adalah:

$$
\mathrm{Y}=3,112+0,384 \mathrm{X} 1+0,207 \mathrm{X} 2
$$

Model persamaan yang diperoleh menyatakan nilai koefisien regresi bagi variabel X1 menunjukkan besaran 0,384 dengan arah yang positif terhadap variabel dependen. Hasil ini diinterpretasikan bahwa differensiasi produk mempunyai pengaruh bersifat positif terhadap keputusan pembelian konsumen; atau, jika perusahaan mempertinggi intensitas strateginya melalui differensiasi produk maka dipandang bisa memperkuat keputusan pembelian konsumen atas sepeda motor merek Yamaha Mio di Kota Langsa, dengan asumsi bahwa faktorfaktor lain tidak mengalami perubahan. 
Persamaan yang diperoleh tersebut juga menyatakan nilai koefisien regresi bagi variabel X2 menunjukkan besaran 0,207 dengan arah yang positif terhadap variabel dependen. Hasil ini diinterpretasikan bahwa citra merek memberikan pengaruh bersifat positif atas keputusan pembelian konsumen; atau, jika perusahaan mempertinggi intensitas strateginya melalui citra merek maka dipandang bisa memperkuat keputusan pembelian konsumen atas sepeda motor merek Yamaha Mio di Kota Langsa, dengan asumsi bahwa faktor-faktor lain tidak mengalami perubahan.

Apabila diperbandingkan nilai koefisien regresi yang diperoleh, maka differensiasi produk $(\mathrm{X} 1=0,384)$ dinyatakan memiliki pengaruh yang dominan terhadap keputusan pembelian konsumen terhadap sepeda motor merek Yamaha Mio di Kota Langsa dibandingkan citra merek $(X 2=0,207)$. Hasil ini mengidentifikasi bahwa jika produsen sepeda motor matic merek Yamaha Mio bermaksud untuk mempertinggi keputusan pembelian dari konsumen terhadap produknya tu, maka penggunaan strategi differensiasi produk lebih direkomendasikan dibandingkan melalui penonjolan citra merek. Hal ini karena diduga bahwa konsumen atas produk itu bersikap lebih sensitif terhadap faktor keunikan yang mendifferensiasi produk yang bersangkutan dibandingkan produk pesaing lain, yang selanjutnya didukung oleh upaya perusahaan untuk mendorong terciptanya citra merek yang positif di dalam benak konsumen sasarannya.

\section{Tabel 4. Hasil Analisis Regresi Berganda dan Uji Hipotesis}

\begin{tabular}{llccc}
\hline \multicolumn{1}{c}{ Variabel } & & $\mathrm{B}$ & $\mathrm{t}$ & Sig. t \\
\hline Konstanta & & 3,112 & 4,643 & 0,000 \\
Differensiasi Produk & & 0,384 & 3,210 & 0,037 \\
Citra Merek & & 0,207 & 3,046 & 0,042 \\
\hline R-Square & $=$ & 0,319 & & \\
Adjusted R-Square & $=$ & 0,297 & & \\
F & $=$ & 4,552 & & \\
Sig. F & $=$ & 0,035 & & \\
\hline
\end{tabular}

Sumber: Data primer diolah, 2019.

\section{Pembuktian Hipotesis}

Dalam bagian ini mula-mula dianalisis pembuktian hipotesis parsial (uji t), dan selanjutnya analisis pembuktian hipotesis simultan (uji F).

Berdasarkan Tabel 4 bisa diidentifikasi bahwa variabel X1 memperoleh Sig. t sebesar 0,037 atau bernilai lebih kecil dari 0,05. Dengan demikian bisa dinyatakan bahwa hipotesis pertama (H1) yang diajukan dalam penelitian ini bisa dibuktikan atau diterima. Dengan kata lain, differensiasi produk terbukti memiliki pengaruh parsial yang signifikan terhadap keputusan pembelian konsumen.

Tabel 4 juga menunjukkan hasil uji parsial atas variabel $\mathrm{X} 2$ diperoleh Sig. $\mathrm{t}$ sebesar 0,042 atau bernilai lebih kecil dari 0,05 . Dengan demikian hipotesis kedua (H2) dinyatakan bisa dibuktikan atau diterima; atau diinterpretasikan bahwa citra merek terbukti memiliki pengaruh parsial yang signifikan terhadap keputusan pembelian konsumen.

Hasil analisis ketiga berdasarkan Tabel 4 mengidentifikasi bahwa hasil uji simultan memperoleh Sig. F sebesar 0,035 atau lebih kecil dari 0,05. Dengan demikian, hipotesis 
ketiga (H3) bisa dibuktikan atau diterima. Berdasarkan hasil tersebut dapat dinyatakan bahwa kedua variabel independen yang dicakup dalam model penelitian ini (yaitu: differensiasi produk dan citra merek) memiliki pengaruh simultan yang signifikan terhadap keputusan pembelian konsumen.

Tabel 4 pada bagian lain menunjukkan hasil $R$-Square yang diperoleh sebesar 0,630. Angka koefisien determinasi itu menyatakan kontribusi dari kedua variabel independen yang termasuk model penelitian ini dalam menjelaskan perubahan-perubahan yang terjadi pada keputusan pembelian konsumen pada produk sepeda motor merek Yamaha Mio di Kota Langsa adalah sebesar 31,9\%. Angka itu, di sisi lain, juga menunjukkan bahwa pola keputusan pembelian konsumen tersebut diidentifikasi dipengaruhi juga oleh faktor-faktor lain yang tidak tercakup dalam model penelitian ini sebesar $68,1 \%$. Faktorfaktor lain itu seperti kualitas purna-jual, aktivitas promosi, harga produk, dan lain-lain.

\section{Pembahasan}

Keputusan pembelian konsumen adalah keputusan seorang konsumen dalam memilih salah satu dari beberapa alternatif produk (Prasetijo \& Ihalauw, 2005; Kotler \& Keller, 2012; Setiadi, 2011). Kondisi ini berarti bahwa sebelum terjadinya suatu keputusan pembelian, pihak konsumen dihadapkan pada beberapa alternatif pilihan produk. Proses pengambilan keputusan yang dilakukannya dapat mempengaruhi hasil dari keputusan pembelian yang diambilnya.

Hasil penelitian ini memperkuat temuan penelitian terdahulu milik Yanti et al. (2013) yang menyatakan bahwa faktor diferensiasi produk memiliki pengaruh signifikan atas keputusan pembelian. Differensiasi produk merupakan kegiatan memodifikasi produk agar lebih menarik yang berkaitan dengan mengubah sedikit karakteristik produk, antara lain kemasan dan tema promosi, tanpa mengubah spesifikasi produk, meskipun upaya itu diperbolehkan (Tjiptono, 2011; Alma, 2014; Schiffman \& Kanuk, 2008). Hasil penelitian ini memperkuat pemikiran bahwa strategi differensiasi produk yang baik dinilai bisa memiliki pengaruh yang positif dan signifikan terhadap keputusan pembelian konsumen. Hal ini karena konsumen diidentifikasi menyukai adanya keunikankeunikan tertentu yang dirasakan saat dirinya menggunakan suatu produk, secara khusus dalam penelitian ini adalah produk sepeda motor merek Yamaha Mio di Kota Langsa.

Terkait pengaruh citra merek terhadap keputusan pembelian konsumen, hasil dari penelitian ini mendukung konsep Kotler dan Keller (2012) serta temuan penelitian Angio (2013). Para akademisi tersebt berargumen bahwa citra merek yang dimiliki suatu produk akan lebih mendorong konsumen untuk melakukan pembelian atas produk yang bersangkutan. Jadi pada dasarnya citra merek yang positif sangat diharapkan bisa diciptakan oleh perusahaan atas produknya. Produk yang memiliki citra merek yang baik dinilai akan memberikan rasa nyaman dan persepsi masyarakat yang positif kepada produk tersebut. Kondisi ini selanjutnya memperkuat keputusan pembelian mereka atas produk tersebut sehingga volume penjualan yang dicapai perusahaan mengalami peningkatan. Dengan demikian, strategi citra merek yang tepat dipandang bisa memunculkan pengaruh positif dan signifikan terhadap pembelian konsumen. Secara khusus, hasil penelitian ini membuktikan bahwa jika sepeda motor merek Yamaha Mio memiliki citra merek yang tinggi maka konsumen di Kota Langsa menjadi lebih tertarik melakukan pembelian atas produk tersebut.

Hasil analisis terakhir membuktikan bahwa kedua variabel independen yang dianalisis dalam penelitian ini memiliki 
pengaruh yang positif dan signifikan terhadap variabel dependen, baik secara parsial maupun simultan. Hasil analisis terakhir ini memperluas temuan-temuan empiris yang diperoleh Yanti et al. (2013), Ristiawan \& Farida (2015) serta Angio (2013) yang menyatakan bahwa differensiasi produk dan citra merek memiliki pengaruh signifikan atas keputusan pembelian konsumen. Berdasarkan hasil ini, pihak produsen perlu mempertimbangkan baik diferensiasi produk maupun citra merek secara bersama-sama di dalam penentuan strategi pemasaran produk Yamaha Mio miliknya. Rekomendasi ini diberikan karena hasil penelitian ini membuktikan bahwa kedua faktor itu sangat mempengaruhi penguatan keputusan pembelian konsumen atas produk itu.

\section{SIMPULAN}

Berlandaskan hasil-hasil yang diperoleh dalam penelitian ini disimpulkan bahwa differensiasi produk serta citra merek memiliki pengaruh yang positif dan signifikan terhadap keputusan pembelian yang diambil konsumen atas produk sepeda motor merek Yamaha Mio di Kota Langsa, baik secara parsial maupun simultan. Hasil penelitian juga mengidentifikasi bahwa differensiasi produk memiliki pengaruh dominan terhadap keputusan pembelian konsumen tersebut dibandingkan citra merek.

Hasil analisis koefisien determinasi lebih lanjut mememberikan identifikasi bahwa differensiasi produk dan citra merek hanya berkontribusi relatif kecil dalam menjelaskan perubahan-perubahan dari keputusan pembelian konsumen atas sepeda motor matic merek Yamaha Mio di Kota Langsa. Sementara masih terdapat sejumlah faktor lain yang diduga turut mempengaruhi keputusan pembelian konsumen tersebut namun tidak dimasukkan dalam model penelitian ini.
Berdasarkan beberapa kesimpulan itu, maka dimunculkan beberapa rekomendasi yang diharapkan dapat menjadi referensi tambahan bagi pihak-pihak yang tertarik atau berkepentingan. Rekomendasi pertama adalah bahwa perusahaan hendaknya meningkatkan strategi differensiasi produk yang terfokus pada produk sepeda motor merek Yamaha Mio yang irit bahan bakar. Penonjolan keunikan produk pada aspek tersebut dinilai akan menciptakan nilai yang tinggi dan membentuk persepsi positif dalam benak para konsumen sasaran, sehingga mereka semakin kuat keputusannya untuk membeli produk tersebut.

Rekomendasi kedua adalah bahwa dalam upaya meningkatkan citra merek dari produk, hendaknya perusahaan menambah variasi Yamaha Mio dengan bentuk yang lebih sporty dan warna yang lebih bervariasi. Strategi penambahan variasi itu dinilai akan mempertinggi citra merek dari sepeda motor merk Yamaha Mio di mata konsumen serta dapat meningkatkan daya saing produk tersebut dalam situasi persaingan dengan sesama motor matic lain.

Penelitian-penelitian selanjutnya direkomendasikan untuk menambah variabelvariabel lain yang diduga bisa mempengaruhi keputusan pembelian konsumen, seperti kualitas pelayanan purna-jual, aktivitas promosi, harga produk itu sendiri, harga produk pesaing, dan lain sebagainya. Dengan memperluas lingkup penelitian ini pada lebih banyak variabel maka akan memperdalam pemahaman tentang variabel-variabel yang mempengaruh keputusan pembelian yang dilakukan konsumen atas produk sepeda motor merek Yamaha Mio secara khusus.

\section{REFERENSI}

Alma, B. 2014. Manajemen Pemasaran dan Pemasaran Jasa. Bandung: Alfabeta. 
Angio, I. 2013. Pengaruh Citra Merek terhadap Keputusan Pembelian Motor Yamaha Mio Soul di Kota Gorontalo (Studi Kasus pada PT. Hasjrat Abadi). Jurnal Ilmu Manajemen. 1(1): 1-14.

Ferrinadewi, E. 2010. Merek dan Psikologi Konsumen. Jakarta: Graha Ilmu.

Ghozali, I. 2011. Aplikasi Analisis Multivariate dengan Program SPSS. Semarang: Badan Penerbit Universitas Diponegoro.

Gunawan, M. 2012. Manajemen Pemasaran. Jakarta: Salemba Empat.

Kertajaya, H. 2011. Positioning, Differensiasi, dan Brand. Jakarta: Gramedia Pustaka Utama.

Kotler, P. \& Amstrong, G. 2012. PrinsipPrinsip Pemasaran. Jakarta: Erlangga.

Kotler, P. \& Keller, K.L. 2012. Manajemen Pemasaran. Edisi 14. Jakarta: Indeks.

Mahmudah, I.S. \& Tiarawati, M. 2014. Pengaruh Kualitas Produk, Citra Merek, dan Harga terhadap Keputusan Pembelian Pond's Flawless White. BISMA: Bisnis dan Manajemen. 6(2): 98-105.

Porter, M.E. 2018. Keunggulan Bersaing: Menciptakan dan Mempertahankan Kinerja Unggul. Cetakan ke-2. Jakarta. PT. Gelora Aksara Pratama.

Prasetijo, R. dan Ihalauw, J.I.O.I. 2005. Perilaku Konsumen. Yogyakarta: ANDI Offset.

Prasetyo, B. \& Jannah, L.M. 2016. Metode Penelitian Kuantitatif. Jakarta: PT. RajaGrafindo Persada.
Ratri, L.E. 2010. Strategi Memenangkan Persaingan Pasar. Jakarta: Salemba Empat.

Ristiawan, D. \& Farida, L. 2015. Pengaruh Citra Merek (Brand Image) terhadap Pengambilan Keputusan Pembelian Sepeda Motor Suzuki Satria FU 150 CC di Kota Pekanbaru (Studi Kasus pada Konsumen PT. Riau Jaya Cemerlang). JOM Fisip. 2(2): 1-11.

Schiffman, L.G. dan Kanuk, L.L. 2008. Perilaku Konsumen. Jakarta: Indeks.

Setiadi, N, 2011. Perilaku Konsumen: Perspektif Kontemporer pada Motif, Tujuan, dan Keinginan Konsumen. Jakarta: Kencana Prenada Media.

Sugiyono. 2012. Metode Penelitian Bisnis. Bandung: Alfabeta.

Sunyoto, D, 2014. Dasar-Dasar Manajemen Pemasaran (Konsep, Strategi, dan Kasus). Yogyakarta: CAPS (Center of Academic Publishing Service).

Tjiptono, F. 2008. Strategi Pemasaran. Yogyakarta: Andi.

Tjiptono, F. 2011. Pemasaran Jasa. Edisi pertama. Malang: PT. Bayu Media Publishing.

Yanti, P.Y., Kirya, K. \& Meitriana, M.A. 2013. Pengaruh Strategi Diferensiasi terhadap Keputusan Pembelian Sepeda Motor Honda atau Yamaha. Jurnal Pendidikan Ekonomi Undiksha. 3(1): 1-10. 